\title{
Extremism: A cover for ignorance
}

\begin{tabular}{|c|c|}
\hline \multicolumn{2}{|c|}{$\begin{array}{l}\text { Author: } \\
\text { Zeinab Barkhordari }{ }^{1,2}\end{array}$} \\
\hline \multicolumn{2}{|c|}{$\begin{array}{l}\text { Affiliations: } \\
{ }^{1} \text { Department of Islamic } \\
\text { Philosophy and Theology, } \\
\text { Faculty of theology, } \\
\text { University of Tehran, Iran }\end{array}$} \\
\hline $\begin{array}{l}{ }^{2} \text { Department } \\
\text { Religion and I } \\
\text { Faculty of The } \\
\text { Religion, Univ } \\
\text { Pretoria, Sout }\end{array}$ & $\begin{array}{l}\text { f Science of } \\
\text { lissiology, } \\
\text { logy and } \\
\text { rsity of } \\
\text { Africa }\end{array}$ \\
\hline \multicolumn{2}{|c|}{$\begin{array}{l}\text { Research Project Details: } \\
\text { Project Leader: M. Sukdaven (D) } \\
\text { Project Number: } 04616546\end{array}$} \\
\hline \multicolumn{2}{|c|}{$\begin{array}{l}\text { Description: } \\
\text { Prof. Barkhordari is } \\
\text { participating in the rese } \\
\text { project, 'Religion in Dial } \\
\text { directed by Dr Maniraj } \\
\text { Sukdaven, Department } \\
\text { Science of Religion and } \\
\text { Missiology, Faculty of } \\
\text { Theology and Religion, } \\
\text { University of Pretoria. }\end{array}$} \\
\hline \multicolumn{2}{|c|}{$\begin{array}{l}\text { Corresponding author: } \\
\text { Zeinab Barkhordari, } \\
\text { barkhordariz@ut.ac.ir }\end{array}$} \\
\hline \multicolumn{2}{|c|}{$\begin{array}{l}\text { Dates: } \\
\text { Received: } 07 \text { June } 2018 \\
\text { Accepted: } 27 \text { July } 2018 \\
\text { Published: } 26 \text { Nov. } 2018\end{array}$} \\
\hline \multicolumn{2}{|c|}{$\begin{array}{l}\text { How to cite this article: } \\
\text { Barkhordari, Z., 2018, } \\
\text { 'Extremism: A cover for } \\
\text { ignorance', HTS Teologiese } \\
\text { Studies/Theological Studies } \\
\text { 74(3), a5138. https://doi. } \\
\text { org/10.4102/hts.v74i3.5138 }\end{array}$} \\
\hline \multicolumn{2}{|c|}{$\begin{array}{l}\text { Copyright: } \\
\text { (C) 2018. The Author } \\
\text { Licensee: AOSIS. This } \\
\text { is licensed under the } \\
\text { Creative Commons } \\
\text { Attribution License. }\end{array}$} \\
\hline Read online & \\
\hline 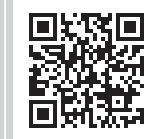 & $\begin{array}{l}\text { Scan this QR } \\
\text { code with your } \\
\text { smart phone or } \\
\text { mobile device } \\
\text { to read online. }\end{array}$ \\
\hline
\end{tabular}

The explanation of the relation between religiousness (being religious; doing according to one's religion's recommendations) and extremism depends on the different types of religiousness. Religiousness in terms of its religious theme can be divided into four types: (1) religiousness with an epistemological theme, (2) religiousness with a moral theme (virtue-oriented behaviours and habits), (3) identical religiousness with a religiousidentification theme and (4) ritual religiousness, with the theme of religious rituals. Islamic religiousness is a combination of all four types. This religiousness is based on episteme. These elements, as mentioned sequentially, are based on each other, and the layer beneath is epistemological religiousness. Lack of one of the three types makes a person tend towards reductionist religiousness, but lack of episteme makes an individual tend towards extremism. Epistemological religiousness is based on self-knowledge. Religiousness that is based on selfknowledge is the main reason for internal and external moderation; religiousness of extremism is the result of self-ignorance and covering up one's ignorance.

\section{Introduction}

This article discusses an issue concerning the religious background of extremism.

Infectious extremism does not have objective or universally accepted definitions. At the same time, extremism can be functionally objective on all levels (individual, group, society nation and global), to the extent that social actors in their cultural environment construct their enemies as such (Klip 2011:9).

The relation between religiousness and extremism is one of the most important issues in the psychology and sociology of religion (see Karimova et al. 2013; Kressel 2007). So the explanation of this relation is important. Extremism is deviation from moderation. As is mentioned in the holy Qur'an: 'Thus we have made you a moderate community' (Q 2:143); ${ }^{1}$ moderation and avoidance of extremism in everything is the interpretation of this verse.

Episteme has the main role in moderation. Imam $\mathrm{Ali}^{2}$ (peace be upon him [PBUH]) says, ‘[y]ou will not find an ignorant person, but at one extreme or the other (i.e. a person who neglects or a person who exaggerates)' (Askari Jafery 1978, saying No. 70). Deviation from moderation and getting stuck in extremism originates in ignorance. In the case of religion, this point guides us to what leads to extremism in religiousness. However, we ask what kind of episteme is useful here? And how does ignorance lead to extremism?

\section{Concept of ignorance}

'Ignorance' ${ }^{3}$ has two interlocking meanings in the Arabic language: one is counter to knowledge and the other is counter to patience. 'Lack of knowledge or information' is the common meaning of 'ignorance', as most scholars have mentioned, but in some Arabic dictionaries the term also refers to the opposite of patience (Faris \& Zakar 2013:69). The sense of continuity is manifested in self-knowledge.

The link between episteme and moderation can be seen in the analysis of the concept of ignorance in the Arabic language. As mentioned, the opposite of the word jahl [ignorance] is two linked concepts: hilm and ilm, which mean 'patient' and 'knowledge', respectively. Patience is the ability to manage feelings in a moderate way and the ability to stay away from extremism.

\footnotetext{
1.

2.Imam Ali (PBUH) is the cousin and son-in-law of Muhammad (PBUH), the prophet of Islam and the first Imam of Shia Muslim from 632 to 661 . He ruled as the fourth caliph from 656 to 661 , after the prophet.
} 
These two linked concepts are shown in self-knowledge as the process of knowing the self, which is based on consciousness and being patient. One who has self-knowledge is conscious and patient.

Religiousness based on self-knowledge is the main reason for internal and external moderation; religious extremism is caused by being ignorant about the self and is a cover for the ignorance of a religious person. Most great religions emphasise self-knowledge, as Imam Ali says: 'Whosoever knows him/herself knows his/her Lord' (ibn Abi al-Hadid, n.d., vol. 20:292). Then a kind of religiousness based on selfknowledge is the critical cause of internal and external moderation. Religious extremism has a mutual relationship with self-ignorance.

On the one hand, religious extremism is the consequence of self-ignorance; on the other hand, a person who is selfignorant uses extremism as a veil for his or her ignorance, as a psychological defence mechanism. Whoever ignores himself or herself is conscious of being self-ignorant and is bothered by this consciousness and its bad consequence. Such a person looks for a refuge to escape from this painful situation. He or she finds in focusing on 'others' and also 'eliminating' the other aspects of religion, in which all are ordered to focus on themselves, two spaces of refuge. Being the enemy of 'others' and denying the other aspects of religion leads to excommunication (takfir).

This sequence of events leads to extremism and it is also a defective cycle: more ignorance, more pain, more emphasis on those things can help the self-forgetter to reduce the pain of self-ignorance, then more extremism that increases self-ignorance. Such a person excels at the other sides of religiousness, so these sides go out of moderation!

\section{Epistemological religiousness and self-knowledge}

Epistemological religiousness based on religious teaching is the result of an individual's knowledge of four things: fourthly, God; secondly, him- or herself; thirdly, other people; and fourthly, everything else (e.g. nature, animals, etc.). This tetrahedral understanding of epistemological religiousness is based on self-knowledge. If one's religiousness is not based on self-consciousness, as an ongoing process, it provides grounds for extremism in the other three sides of knowledge. Therefore, one who knows himself or herself knows his or her God and in the light of this knowledge knows the way in which to act in justice to others.

This theory is illustrated in Figure 1.

Imam Ali (PBUH) also says, 'The best knowledge is the knowledge of man him/herself' (Jaffer 2012, saying No. 2935). He knows self-knowledge as the base of other knowledge, and he also says: 'How can somebody know others, when he/she doesn't know him/herself?'(2012, saying No. 518).

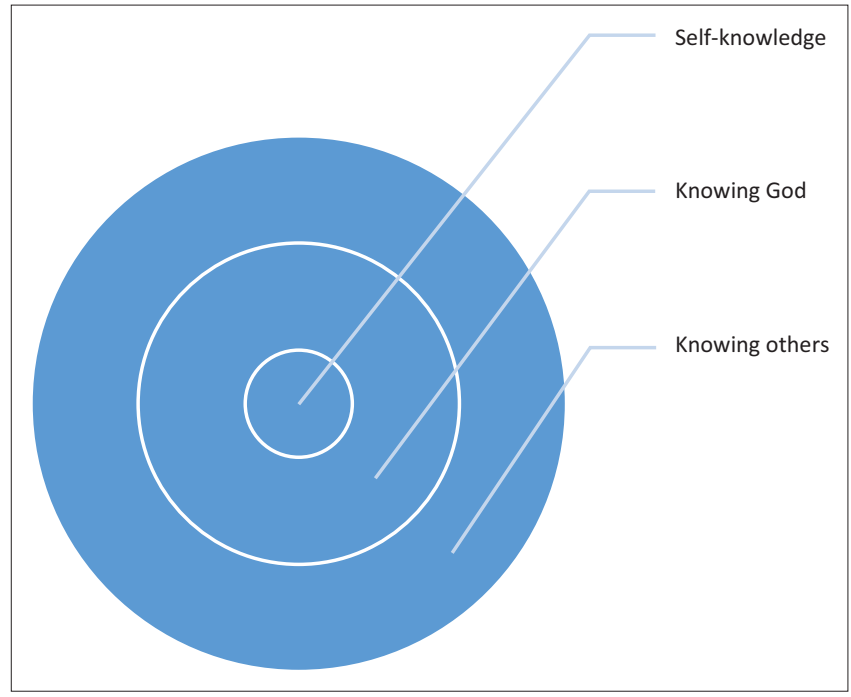

FIGURE 1: This tetrahedral understanding of epistemological religiousness.

\section{Types of religiousness}

Religiousness has different types. Extremism is one of these types. Extremism has a psychological and social background. Racial prejudice and religious prejudice have been the main causes of extremism leading to violence and genocide. So the relation between religiousness and extremism is one of the most important issues in the psychology and sociology of religion. Religious extremism originated in religious prejudice and a particular type of religiousness. So the elaboration of this relation depends on the distinction of the religiousness types.

There are many classifications of religiousness, based on the distinction of Allport and Ross (1967) between internal and external religiousness. Before this, the distinction of different religiousnesses existed in the words of religious leaders. For example, Imam Ali (PBUH) differentiates three types of religiousness:

1. trader-like religiousness

2. slaver-like religiousness

3. freeman-like religiousness.

A group of people worshipped Allah out of desire for reward, surely; this is the worship of traders. Another group worshipped Allah out of fear; this is the worship of slaves. Still another group worshipped Allah out of gratefulness; this is the worship of free men. (Askari Jafery 1978, saying No. 237)

If we take a structuralist perspective on the great religions, we can consider that religion contains four elements: religious episteme, religious moral, religious identity and religious rituals. Then, religiousness can be divided into four types according to the presence, absence and frequency of each of these elements:

1. religiousness, with the theme of belief and religious episteme 


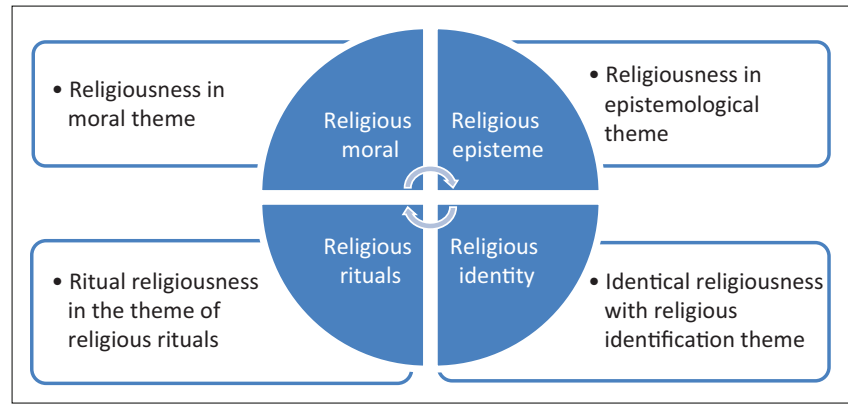

FIGURE 2: Islam emphasises of all four elements.

2. moral religiousness, with the theme of virtue-oriented behaviour and habits

3. identical religiousness, with the theme of religious identity

4. ritual religiousness, with the theme of rituals and prayers.

Considering that Islam emphasises all four elements, religiousness, in the Islamic discourse, is a proper combination of all of these elements. These elements, as mentioned, are based on each other, and the underlying layer is epistemological religiousness (see Figure 2).

The lack of one of these four elements misleads religion from its systematic form and its perfection, and it leads to reductionist religiousness.

As we know, in Islam, religious beliefs are not simulative. Shias and a considerable group of Sunnis, like Mu'tazilite, ${ }^{4}$ emphasise the wisdom in religious beliefs. A religious person in Shia Islam, Mu'tazilite and the traditions of many other sects should reach a belief in epistemic meaning and true justified belief. Because of this, one of the definitions of religious belief in the idea of scientists is certain confirmation.

The element of episteme has a moderating role in religiousness. Deviation from moderation and getting stuck in extremism or negligence originates in ignorance. Epistemological religiousness has a tetrahedral structure; therefore, as a structure it can be balanced or unbalanced. The tetrahedral knowledge is based on self-knowledge. If an individual's religiousness is not placed on his or her selfconsciousness (as mentioned), as an ongoing process, it creates a tendency toward extremism in the three other sides of knowledge. This disorder in epistemological religiousness leads to a lack of moderation in the other elements of religiousness. The analogous saying from Imam Ali (PBUH) is: 'Anyone who knows himself has achieved the result of any knowledge and knowledge' (Jaffer 2012, saying No. 270).

On the advice of Daphni Monastery, the sentence 'know yourself' has been the doctrine for training and it is the core of schools of different religions and morality (Park 1939:396). This knowledge, meant to convey the importance of finding yourself, is the reason for internal and external moderation. One who does not reach internal moderation cannot be at 4.This is a school of Islamic theology (Robinson 1998). peace with others; as Plato says, it is the core of 'peace with himself and with all mankind' (1948:11).

An individual's immoderate inside causes his or her relations with people and nature to be characterised as extremist or negligent.

Thinking about the link between religious episteme and moderation needs some clarification:

1. Reductionist religiousness lacks the religious episteme element and leads the religious person to extremism. For example, when a person is satisfied only by a religious identity in religiousness and is deprived of religious insight, he or she tends to have religious prejudice, meant as identity prejudice, and to reach violent extremism to protect and expand his or her religious identity.

2. Those who confuse the type of religiousness with religiousness itself generally identify extremism as a requirement for religiousness and think of religiousness and extremism as being the same destination instead of identifying extremism as a result of one of the types of religiousness. Based on this opinion, a two-way road appears: to be away from the sufferings of extremism we should fight religiousness, or to protect religiousness we should consider extremism as a justified concept.

3. A moderate and reasonable way to get away from the so-called two-way road is to design and perform religious education programmes in such a way that their result would be a moderate religiousness, meaning that it has each of the four elements. This shows the importance of moral training programmes and the role of the media in religious countries.

\section{Conclusion}

On the one hand, according to the rational and religious heritage of mankind, self-knowledge is the most important and useful knowledge. On the other hand, a complete religion has four essential aspects: epistemological, ritual, moral and identification. So religious episteme is the most important of the aspects. If it doesn't exist, an individual's religiousness can be based on simulation, religious feelings and superstitious beliefs; then the other elements can lead to extremism and violence. The core of episteme is selfknowledge. A person who ignores himself or herself has an unconscious psychological reaction to compensate for the inevitable pain of self-ignorance. So he or she focuses on the three other parts of religion to alleviate the pain. Without episteme, the other three parts exceed reasonable limits or bounds. So extremism is a cover for ignorance.

As far as all four types of religiousness are found in Islam, true religiousness is the coherence of three themes of religiousness based on an epistemological one. The link between religious episteme and moderation declares that (1) the existence of reductionist religiousness, (2) extremism generally is a requirement for religiousness, and (3) improving selfknowledge is a way to have a moderate religiousness. 


\section{Acknowledgements}

\section{Competing interests}

The author declares that he or she has no financial or personal relationships which may have inappropriately influenced him or her in writing this article.

\section{References}

Allport, G.W. \& Ross, J.M., 1967, 'Personal religious orientation and prejudice', Journal of Personality and Social Psychology 5, 423-443. https://doi.org/10.1037/ h0021212

Askari Jafery, S.M., 1978, Nahjul Balagha Sermons, letters and sayings of Imam Ali (A.S.), 3rd edn., Islamic Seminary for WSMO, Bombay, India.

Faris, I. \& Zakar, F.I., 2013, Mu'jam maqayis al-lughah, vol. 4, Turath for solutions, p. 69. ISBN: $9957688456,9789957688455$.
Ibn Abi al-Hadid, Izz al-Din Abu al-Hamid bin Hibat-Allah, n.d., Sharh Najh ul Balagha Dar al Kutub al Arabiyya al-Kubra, Cairo.

Itani, T., 2012, The Quran English translation, ClearQuran, Dallas, TX. ISBN 9781467948746.

Jaffer, T.R., 2012, Ghurar Al-Hikam Wa Durar Al-Kalim [Exalted Aphorisms and pearls of speech], a collection of Aphorisms of Imam 'Ali ibn Abi Talib, Compiled by Qadh Nasih al-Deen Abu al-Fath 'Abd al-Wahid Ibn Muhammad Al-Tamimi al-Amudi (d. $510 \mathrm{AH}$ ), Ansariyan Publications, Qum. ISBN-10: 9642192802 ISBN-13: 978-9642192809.

Karimova, R., Aksakalova, Z., Seidaliyevich, K.D. \& Bolatovna, D.P., 2013, 'Social and psychological aspects of religious extremism prevention amongst youth' 1st Annual International Interdisciplinary Conference, AllC, Azores, Portugal, April 24-26.

Klip, A., 2011, 'The ontology and epistemology of extremism', ENDC Proceedings 14, 9-25. Kressel, N.J., 2007, Bad faith: The danger of religious extremism, Prometheus books, Amherst, New York.

Plato, 1948, Plato's the republic, Books Inc., New York.

Robinson, N., 1998, Ash'ariyya and Mu'tazila, viewed n.d., from https:// muslimphilosophy.com 